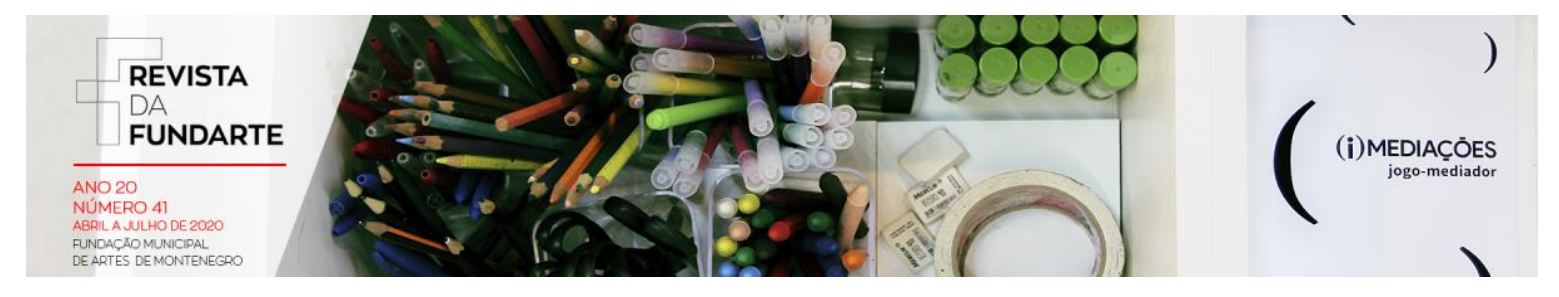

\title{
EM BUSCA DE UM TEATRO SAGRADO: ENCONTROS E TRAVESSIAS NO OPEN PROGRAM OF WORKCENTER OF J. GROTOWSKI AND T. RICHARDS
}

\author{
Bruno Leal Piva
}

DOI: http://dx.doi.org/10.19179/2F2319-0868.674

PIVA, Bruno Leal. Em busca de um teatro sagrado: encontros e travessias no Open Program of Workcenter of J. Grotowski and T. Richards. Revista da FUNDARTE. Montenegro, p.01-21, ano 20, no 41, Abril/Junho de 2020.

Disponível em: http://.seer.fundarte.rs.gov.br/index.php/RevistadaFundarte/index> 30 de junho de 2020. 


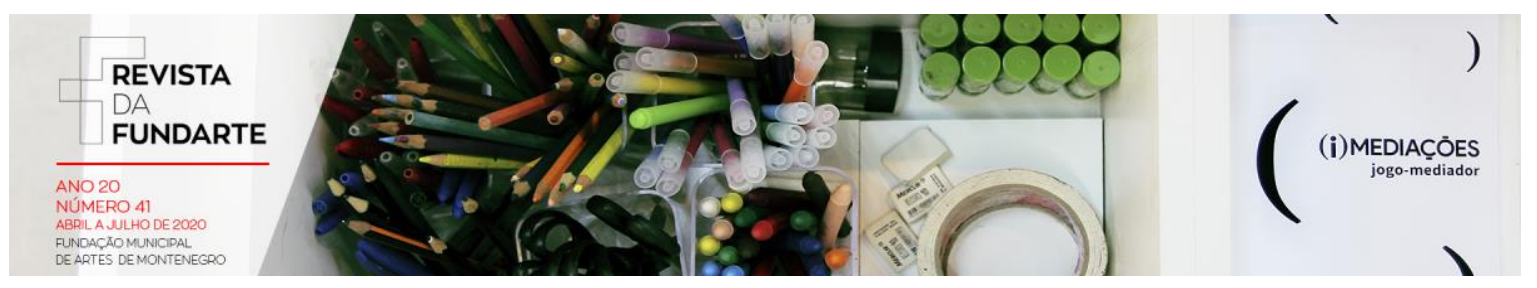

\title{
EM BUSCA DE UM TEATRO SAGRADO: ENCONTROS E TRAVESSIAS NO OPEN PROGRAM OF WORKCENTER OF J. GROTOWSKI AND T. RICHARDS
}

Bruno Leal Piva'

\begin{abstract}
Resumo: O presente artigo tem como finalidade analisar a importância da interculturalidade, tratada aqui como hibridez cultural, no Open Program of Workcenter of Jerzy Grotowski and Thomas Richards, inserido em sua última fase de pesquisa denominada Arte como Veículo. Observa-se o uso de técnicas e tradições não ocidentase cantigas ancestrais afro-caribenhas, para o encontro da sensibilidade e sinceridade interiores de si através do outro. Centra-se, para tanto num processo de resgate do corpo-memória ou espaço "sagrado", produzido por ações vocais e corporais experimentados pelos atuantes no referido Programa.

Palavras-chave: Interculturalidade; Tradição; Corpo-Voz.

\section{LOOKING FOR A SACRED THEATER: MEETINGS AND CROSSIES IN OPEN PROGRAM OF WORKCENTER OF J. GROTOWSKI AND T. RICHARDS}

Abstract: This present article has the finality to analyze the importance of the interculturality, treated here as cultural hybridity, in Open Program of Workcenter of Jerzy Grotowski and Thomas Richards, inserted in his last fase of research named Art as Vehicle.The use of not western technicques and afro-caribbean ancestral songs is observed to meet the inner sensitivity and sincerity of oneself through of the other. To this the end, it focuses on a process of the body-memory or "sacred" space, produced by vocal and body actions experienced by those who work in the workshop of that Program.

Keywords: Interculturality; Tradition; Body-Voice.

\section{Introdução ou Ponto de Partida}

Em busca da desconstrução e reconstrução de paradigmas para o fazer teatral e levando em consideração suas ressignificações em prol das transformações das práticas teatrais, este estudo volta-se para a preocupação em observar o papel

\footnotetext{
${ }^{1}$ Ator-artista, pesquisador e professor. Mestre em Artes Cênicas pela Faculdade de Ciências Sociais e Humanas da Universidade Nova de Lisboa (Portugal). Bacharel e Licenciado em Letras Português/Espanhol pela Universidade de São Paulo (USP).
}

PIVA, Bruno Leal. Em busca de um teatro sagrado: encontros e travessias no Open Program of Workcenter of J. Grotowski and T. Richards. Revista da FUNDARTE. Montenegro, p.01-21, ano 20, no 41, Abril/Junho de 2020.

Disponível em: http://.seer.fundarte.rs.gov.br/index.php/RevistadaFundarte/index> 30 de junho de 2020. 


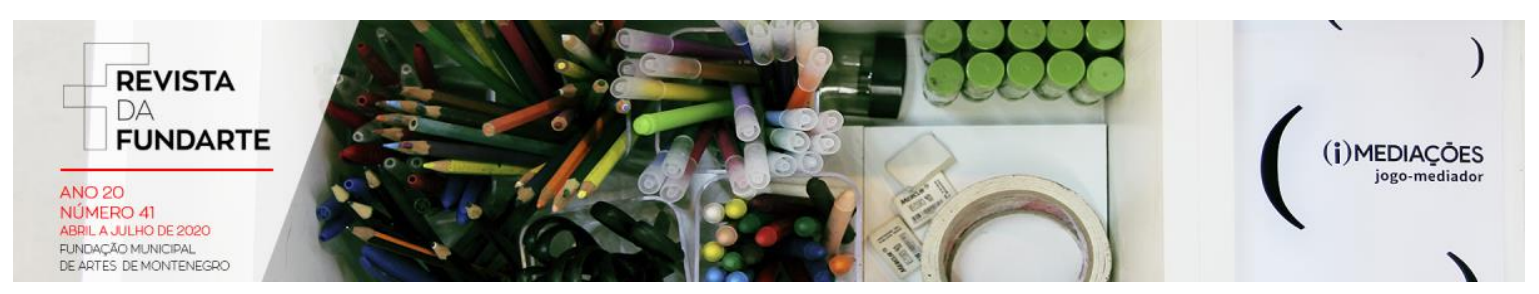

da hibridez cultural ${ }^{2}$ presente na última fase do pensamento artístico de Jerzy Grotowski, mas sem deixar de notar também esse trânsito em toda sua trajetória entre vida e arte, na preparação e no encontro de um terreno (ou corpo) sagrado e orgânico. Neste caminho, o ator/actante ${ }^{3}$ necessita escutar a si e ao outro, transpassando-se por memórias ancestrais na procura de uma sensibilidade e sinceridade interiores, por meio de suas vozes ecoadas e amplificadas em seus corpos-memórias.

Para tanto, a Arte como Veículo, assim designada essa última etapa de pesquisa de Grotowski, traz como legado um trabalho de encontro sagrado e culturamente híbrido do actor/actante, que desperta interesse para essa investigação, sobretudo após uma vivência pessoal na oficina "Comportamento Orgânico e Contato: um Encontro de Trabalho com o Open Program of Workcenter of Jerzy Grotowski and Thomas Richards", cuja realização ocorreu no primeiro semestre de 2015. O núcleo Open Program, dirigido por Mario Biagini, foi criado em 2007, e compartilha suas pesquisas com o outro time do mesmo centro de trabalho, o Focused Research Time in Art as Vehicle, criado em 2008 e dirigido por Thomas Richards. O Workcenter foi criado há mais de 25 anos e trata de propagar e continuar as investigações dos últimos 30 anos de trabalho de Jerzy Grotowski, conjugando pesquisa e criação.

A base para os experimentos dos encontros consiste nas obras e práticas do diretor-encenador-pedagogo polonês que dá nome ao Programa, orientados por Mario Biagini, que conta com actantes-assistentes de diversas partes do mundo e que estão sempre auxiliando na execução dos exercícios. Diariamente, os actantes oficineiros propõem materiais que consideram pertinentes para o desenvolvimento

\footnotetext{
${ }^{2}$ Adota-se o termo "hibridez cultural" para designar a interculturalidade ou transculturalidade presente no trabalho do Workcenter. Sobre discussões conceituais e conteudísticas sociogeográficas, políticopedagógicas e econômico-culturais que divergem sobre a melhor maneira de utilizar os referidos termos, cf. MADEIRA, Cláudia. Híbrido - do Mito ao Paradigma Invasor?. Lisboa: Mundos Sociais, 2010.

${ }^{3} \mathrm{O}$ agente do teatro é sugerido neste trabalho como "actante", que pode ser concebido como aquele que executa ou sofre o ato, segundo adoção de Matteo Bonfitto (2013, p.132).
}

PIVA, Bruno Leal. Em busca de um teatro sagrado: encontros e travessias no Open Program of Workcenter of J. Grotowski and T. Richards. Revista da FUNDARTE. Montenegro, p.01-21, ano 20, no 41, Abril/Junho de 2020.

Disponível em: http://.seer.fundarte.rs.gov.br/index.php/RevistadaFundarte/index> 30 de junho de 2020. 


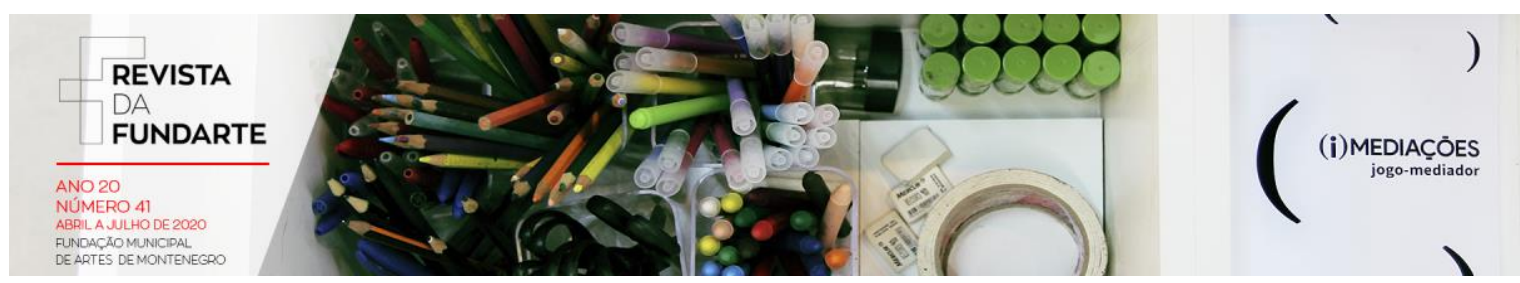

de sua organicidade e de um encontro verdadeiro, consigo e na comunhão com o outro, tanto no primeiro momento, mais sagrado ou ritualístico ${ }^{4}$, como no segundo tempo da oficina, com apresentação de cenas. Mostram ao diretor algum resultado obtido em suas pesquisas, e logo são arrastados para outro lado. Constroem, desconstroem, inserem, retiram, realizam analogias ao texto, sempre tendo em vista a preocupação em estabelecer uma logicidade sensível em seu experimento cênico, apesar da dificuldade dessa contradição.

\section{O Caminho e o Veículo de Jerzy Grotowski}

Para entender melhor os procedimentos que regem o Open Program, cujo cunho localiza-se em a Arte como Veículo, faz-se importante realizar uma breve digressão acerca das outras fases - ou elos da cadeia ${ }^{5}$, como cita Jerzy Grotowski (2010, p. 230) - de estudos do mestre polonês ${ }^{6}$. A primeira etapa é chamada de Teatro do Espetáculo, em que o trabalho do actante, pelas ações físicas, era condicionado à sua desenvoltura estrutural em relação ao espectador, respeitando e inovando as tradições teatrais, mas já com forte teor pedagógico para a formação do artista teatral, e também levando o público a uma sensibilização por via do teatro pobre, ou seja, pela experiência de relacionar-se apenas com os elementos

\footnotetext{
${ }^{4}$ O conceito de Teatro Sagrado é assumido neste trabalho como o definido por Peter Brook (1970), que assim chamava o tipo de teatro do invisível-tornado-visível, em que o espaço cênico é um lugar onde o invisível aparece. Sobre o teatro ritual, remete-se à ideia de Antonin Artaud, em que o teatro ocidental deveria passar por uma grande transformação, sendo antes ritual e mágico. Ainda sobre a aproximação do teatro de Grotowski a um ritual, afirma Hans-Thies Lehmann (2007, p. 266) que "nas encenações de Grotowski o teatro se converte num processo quase ritual, uma vez que a participação emocional de quem assiste se torna constitutiva para o que acontece. O observador acompanha os atores com uma tal proximidade que acaba por entrar no círculo encantado da convivência orgânica."

${ }^{5}$ Grotowski chama de elos os períodos que se sucederam a partir do Teatro dos Espetáculos, que o ligava aos elos posteriores.

${ }^{6}$ Resolve-se adotar os períodos de trabalho de Grotowski citados pelo mesmo (2010, p. 223) e de Bonfitto (2013, p. 100), apesar de ser apontado por De Marinis e Richard Schechner, por exemplo. o período do Objective Drama entre 1983 a 1985.
}

PIVA, Bruno Leal. Em busca de um teatro sagrado: encontros e travessias no Open Program of Workcenter of J. Grotowski and T. Richards. Revista da FUNDARTE. Montenegro, p.01-21, ano 20, no 41, Abril/Junho de 2020.

Disponível em: http://.seer.fundarte.rs.gov.br/index.php/RevistadaFundarte/index> 30 de junho de 2020. 


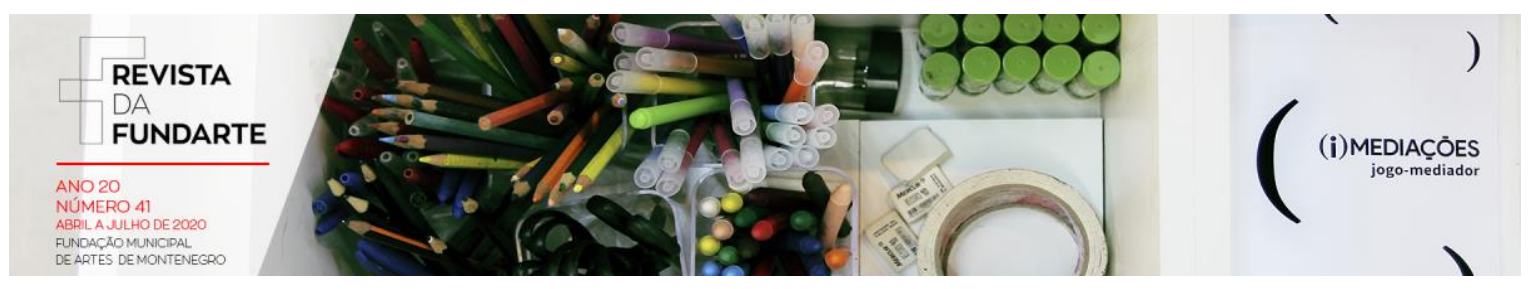

necessários para o alcance de um contato íntimo, de uma organicidade ${ }^{7}$. No entanto, Grotowski percebeu que o papel de espectador deveria insurgir de modo mais ativo no trabalho artístico, como uma reunião ou celebração de um Dia Santo, em que todos os actantes-participantes, ou seja, de dentro e de fora das pesquisas aprofundadas pelo grupo Teatro das 13 Fileiras - que depois se converte em Teatr Laboratorium $^{8}$ - fossem colaboradores ativos - o Parateatro ou Teatro da Participação, por meio das ações físicas e vocais propostas pelos actantes e diretor. Mas logo em seguida, Grotowski (Ibidem, p. 230-231) confessa que, após algumas apresentações nessa fase, quando o grupo de base não estava totalmente capacitado ou quando pretendiam receber mais participantes, a qualidade da proposta decaía e resultava numa série de animações ou descarga de emoções débeis. Assim criou-se o novo elo com o Teatro da Fontes, cuja abordagem era mais solitária, tinha base de trabalho em diversas técnicas estrangeiras (yoga, vudu, zen etc.) e realizava-se em diferentes partes do mundo, no intuito de confrontar o indivíduo e seu lugar no mundo. Nas palavras de Grotowski (Ibidem, p. 231):

[...] procurávamos sobretudo o que o ser humano pode fazer com a própria solidão, como ela pode ser transformada em uma força e em uma relação com aquilo que é chamado de ambiente natural. [...] Com o Teatro das Fontes chegamos a processos fortes e vivos [...] faltou-nos o tempo necessário para continuar porque o programa foi cortado.

Para o autor, tanto o parateatro como o Teatro das Fontes traziam a limitação de fixação, pelos actantes, no plano da horizontalidade, que impedia que as ações ultrapassassem esse plano e transpusessem a energia vital para outros planos, de descoberta de todas as direções e em todos os sentidos. Entretanto, foi a partir do parateatro que foi permitido "colocar à prova a essência da determinação: não se

\footnotetext{
7 Em seu trabalho, Grotowski redefine a noção de organicidade "[...] organicidade indica algo como potencialidade de uma corrente de impulsos, uma corrente quase biológica que vem de "dentro" e que vai terminar numa ação precisa." (RICHARDS, 2011, p.107)

${ }^{8}$ Eugênio Barba relata em A Terra de Cinzas e Diamantes (2006, p. 26) que "A evolução do Teatr 13 Rzedów em Teatr-Laboratorium é o exemplo de um teatrinho que começa como uma vanguarda artístico-literária e termina encarnando um processo criativo que é a tomada de posição artística, política e espiritual.".
}

PIVA, Bruno Leal. Em busca de um teatro sagrado: encontros e travessias no Open Program of Workcenter of J. Grotowski and T. Richards. Revista da FUNDARTE. Montenegro, p.01-21, ano 20, no 41, Abril/Junho de 2020.

Disponível em: http://.seer.fundarte.rs.gov.br/index.php/RevistadaFundarte/index> 30 de junho de 2020. 


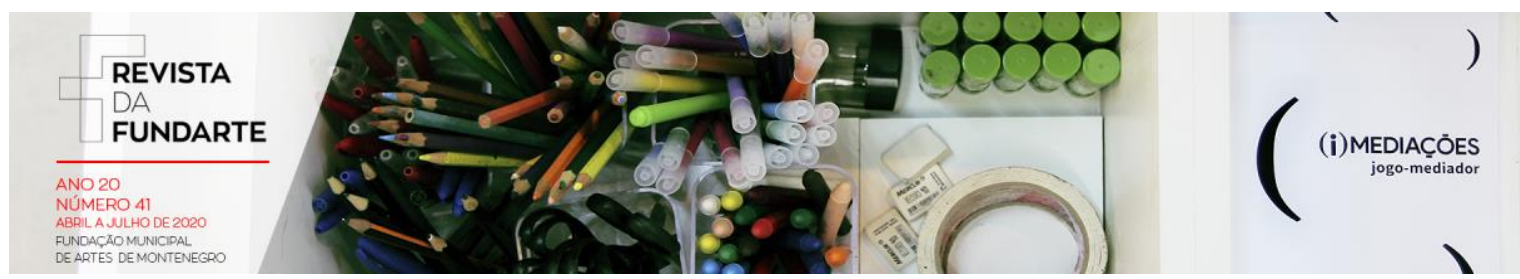

esconder em nada." (Ibidem, p. 231). E também, a seguir (Ibidem, p. 231-232, grifo do autor), diz que

O Teatro das Fontes revelou possibilidades reais. Mas também ficou claro que não podíamos realizá-las in toto ${ }^{9}[. .$.$] . Nunca rompi com a sede que$ motivou o Teatro das Fontes. Contudo a arte como veículo não é orientada ao longo do mesmo eixo: o trabalho procura passar, consciente e deliberadamente, acima do plano horizontal com as suas forças vitais, e essa passagem se tornou A saída: a "verticalidade". [...] a arte como veículo se concentra no rigor, nos detalhes, na precisão comparável àquela dos espetáculos do Teatro Laboratório. Mas atenção! Não é um retorno em direção à arte como apresentação; é a outra extremidade da mesma cadeia.

Assim nasce a arte como veículo. Não como processo independente da trajetória do diretor do Teatr Laboratorium, mas como um caminho subjacente resultante de uma longa estrada repleta de obstáculos, intempéries e imprevistos. Imprevistos esses driblados pela determinação irremitente de um homem que buscava encontrar saídas no mapa perdido do labirinto universal humano.

\section{Cruzando Estradas, Cruzando Fronteiras}

Nessa busca pelo reconhecimento de si, Grotowski transpõe fronteiras e procura em outros lugares algo que em todos os seres existe em comum. Uma espécie de lembrança a ser recordada pelo corpo-memória, de onde quer que seja a pessoa. Um retorno a práticas ancestrais que remeta 0 actante a uma indissociabilidade entre consciência e inconsciência, técnica e tradição. Aqui, e conforme Daniel Reis Plá (2013, p. 146) o corpo

[...] é vivo e responde aos diferentes estímulos externos e internos, mas ainda é território a ser submetido, campo a ser arado, carruagem a ser guiada pelo artista-condutor. A técnica propõe desafios ao corpo, que é conduzido a um objetivo predefinido, provocado a gerar o que ainda não possui $[\ldots]$.

${ }^{9} \mathrm{~A}$ expressão remete à ideia de semelhante à realidade, ou imitação da realidade.

PIVA, Bruno Leal. Em busca de um teatro sagrado: encontros e travessias no Open Program of Workcenter of J. Grotowski and T. Richards. Revista da FUNDARTE. Montenegro, p.01-21, ano 20, no 41, Abril/Junho de 2020.

Disponível em: http://.seer.fundarte.rs.gov.br/index.php/RevistadaFundarte/index> 30 de junho de 2020. 


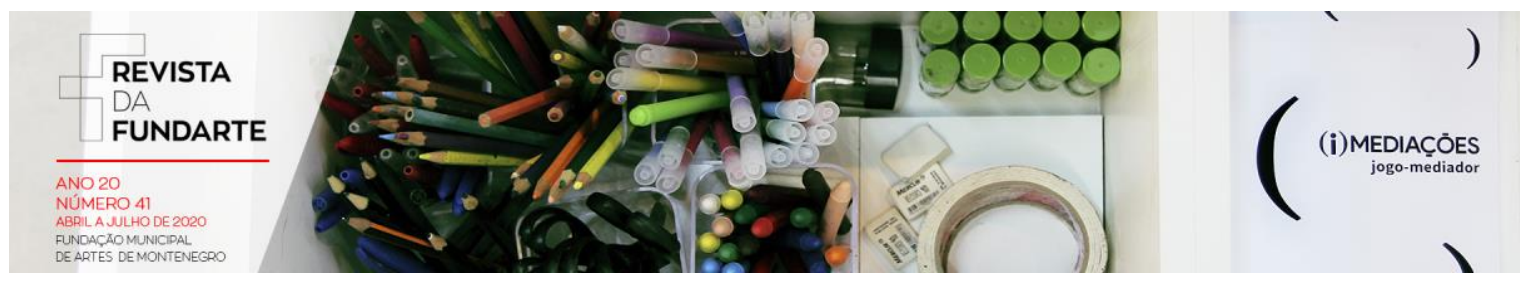

Grotowski procurava encontrar em técnicas ou métodos de diversos contextos culturais maneiras de contribuir para o fazer artístico ocidental, com os quais o corpo pudesse transpassar as barreiras culturais. E ao entrar em contato com outras técnicas advindas de fora, como do sul da Índia, o Kathakali, percebe que o corpo do actante irá encontrar um campo a ser explorado, que é o biológico, e ampliar as capacidades de alargamento desse corpo, na metamorfose entre o ser social e o ser individual.

Estudei todos os principais métodos de treinamento do ator na Europa e fora da Europa. Os mais importantes para os meus objetivos são os exercícios rítmicos de Dullin, as pesquisas de Delsarte sobre as reações extrovertidas e introvertidas, o trabalho de Stanislávski sobre as "ações físicas", o treinamento biomecânico de Meierhold, as sínteses de Valkhtângov. São também particularmente estimulantes para mim as técnicas de treinamento do teatro asiático: em particular a Ópera de Pequim, o Kathakali indiano e o teatro Nô japonês (GROTOWSKI, 2010, p. 105-106)

A inclinação de Grotowski pelo Kathakali, que imbuía sua visão existencial, de acordo com Eugênio Barba (2006, p. 49), foi admitida em conversa com o diretor polonês em Pontedera, Itália, em 1992, e se devia ao fato de sua mãe também ter tido uma forte tendência à crença hinduísta. Não é à toa que a hibridez das relações entre técnicas ocidentais e orientais culminam na excelência da prática teatral no trabalho do Workcenter.

Para melhor compreensão sobre o sentido das múltiplas culturas que se entrecruzam, sem qualquer tipo de domínio de uma sobre a outra, e sim que se estabelecem uma na outra e interferem numa organicidade viva sobre os actantes, e levando em consideração a atuação dos participantes no Open Program of Workcenter..., assume-se aqui o conceito de "hibridez" de Claudia Guerra Madeira (2010, p. 36), quando se expõe que

A coexistência de expressões - híbrido e mestiço -, para tratar o mesmo processo de mistura entre populações, culturas, línguas, coloca desde logo a questão de qual o termo mais adequado para definir fenômenos de cruzamento. No seu dicionário de mestiçagens [...] reveladoras da diversidade de coisas que se misturam - países, cidades, modos, expressões artísticas, produtos, gastronomia, literatura, etc -, Laplantine e

PIVA, Bruno Leal. Em busca de um teatro sagrado: encontros e travessias no Open Program of Workcenter of J. Grotowski and T. Richards. Revista da FUNDARTE. Montenegro, p.01-21, ano 20, no 41, Abril/Junho de 2020.

Disponível em: http://.seer.fundarte.rs.gov.br/index.php/RevistadaFundarte/index> 30 de junho de 2020. 


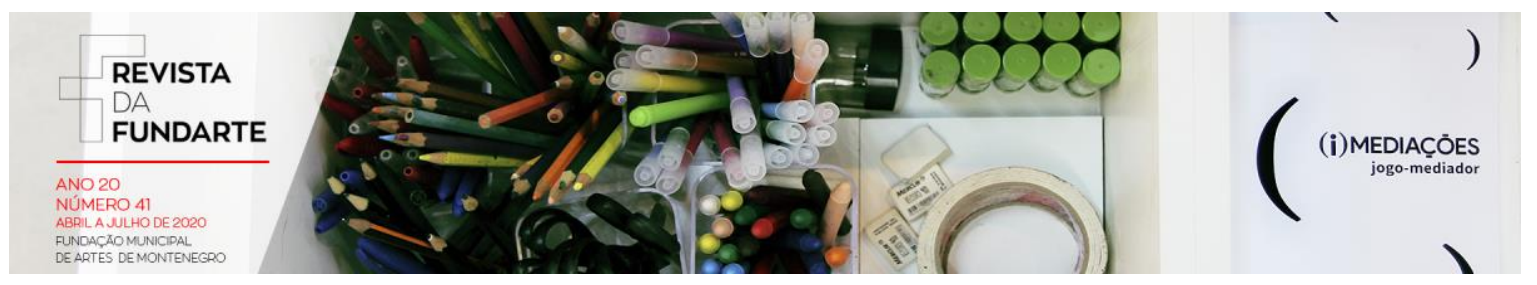

Nouss parecem não ter dúvida que a expressão que melhor as redescobre é "mestiçagem". No prefácio desta obra, definem mesmo mestiçagem pela diferenciação em relação a outros termos, como "mistura", "mixagem", "sincretismo" e, precisamente, "hibridez".

A hibridez insere-se em todo percurso ou travessias propostas por Grotowski, embora nele haja sempre uma preocupação incessante da busca do "eu-interior", mas não apenas como trabalho de investigação para si mesmo, como cita Marco De Marinis (apud Tatiana Motta Lima, 2013, p. 224):

Não se pode dizer que se trata de um trabalho para si mesmo, no qual o indivíduo seja o primeiro e único beneficiário. A ideia, ao contrário, é considerar o indivíduo como um âmbito de busca, como um campo, como um laboratório e como um instrumento. [...] o rigor de fazer o indivíduo um espaço para percorrer e não um valor em si mesmo (De Marinis, 2004, p. 90-91).

Essa busca estaria inserida nas diversas vias que compõem esse espaço culturalmente híbrido, e pelo qual, aparentemente, surge uma contradição para o encontro de si no outro. Mas, talvez, a hibridez dos costumes, hábitos, características, formas, caminhos e procuras, parecem mesmo convencer de que o lugar puro, parece ser um lugar equivocado. E para verificar o retorno a essas raízes "puras", mas não no sentido de formação homogênea, e sim de composição complexa por aspectos heterogêneos, é preciso retornar ao corpo-mente, consciente-inconsciente, num processo contínuo de metamorfose: é preciso falar sobre a tradição.

A tradição na arte como veículo é um elemento norteador do trabalho do Open Program of Workcenter..., que traz estampada em suas indumentárias a miscigenação da mestiçagem ${ }^{10}$, principalmente quando essa mistura diz respeito às propostas levantadas pelos actantes-participantes na sugestão de figurinos compostos por roupas de celebração mais formais ou ritualísticas - ou materiais pertinentes para si nesse encontro - objetos cênicos, ou textos, ou parte de cenário, mas sempre o corpo-voz. No momento do encontro com seres advindos de diversos

10 "Mestiçagem" é o termo adotado para referir-se à hibridez cultural.

PIVA, Bruno Leal. Em busca de um teatro sagrado: encontros e travessias no Open Program of Workcenter of J. Grotowski and T. Richards. Revista da FUNDARTE. Montenegro, p.01-21, ano 20, no 41, Abril/Junho de 2020.

Disponível em: http://.seer.fundarte.rs.gov.br/index.php/RevistadaFundarte/index $>30$ de junho de 2020. 


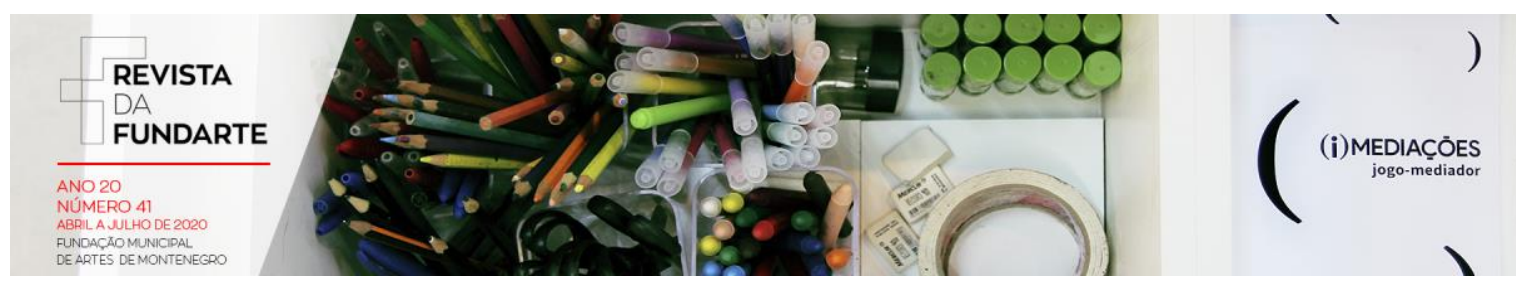

lugares do planeta, o distanciamento contrai-se, cujo tema circunda no reconhecimento de si, num ato de comunhão e troca com o outro.

As diversas tradições tornam-se únicas e plurais, como na ressonância de um pulmão suspirante, à procura de um respiro orgânico e essencial que retém o ar em si, libera e expande para o meio, convergindo e trocando com ares de outros meios. A tradição, torna-se assim, um ponto de equilíbrio substancial que Grotowski usa em favor do dialetismo necessário de experiência para seu teatro sagrado, movido pelo caráter ritualístico de Antonin Artaud, citado por Richard Schechner (2003, p. 20), quando este diz que "Artaud does not say that theater comes from this or that ritual. He argues that theater is - or ought to be - ritual'11.

Nesse sentido, Schechner (2013, p. 52-59) ainda define que o ritual nas artes performativas é uma ação que se estabelece no jogo cênico, e a combinação entre ritual e jogo transforma as pessoas envolvidas de modo temporário, diferente da transformação permanente causada pelos chamados "ritos de passagem". Esse ritual criado dentro da dinâmica das artes cênicas, numa atmosfera sagrada, mas misturada a práticas seculares, sem que haja nenhum tipo de relação com orações ou exaltações religiosas, acontece no trabalho do Open Program...

Como foi citado, Grotowski centra suas propostas em diferentes contextos culturais, a fim de encontrar propostas distintas que impulsionam o actante a dispor de mecanismos que interfiram em seu meio existencial, na desconstrução de máscaras cotidianas impostas pelo pragmatismo social interveniente, no encontro de uma existência além do contato imediatista, isto é, extracotidiano. Para isso, discute um modo de "vivenciar na pele" os conceitos relacionados ao seu organon (Plá, 2003, p. 153):

O organon pode ser entendido como uma resposta de Grotowski à tradição e ao teatro. Ao se voltar para práticas ancestrais, busca nelas aquilo que é perene e vivo. Não é questão de se apegar a um passado congelado, mas sim da criação de uma tradição de si mesmo, no sentido de encontrar nessas práticas um modelo de ação útil ao homem de hoje. Dessa forma,

\footnotetext{
11 Tradução minha: Artaud não defende que o teatro provém deste ou daquele ritual. Ele contesta que o teatro é - ou deveria ser - ritual.
}

PIVA, Bruno Leal. Em busca de um teatro sagrado: encontros e travessias no Open Program of Workcenter of J. Grotowski and T. Richards. Revista da FUNDARTE. Montenegro, p.01-21, ano 20, no 41, Abril/Junho de 2020.

Disponível em: http://.seer.fundarte.rs.gov.br/index.php/RevistadaFundarte/index $>30$ de junho de 2020. 


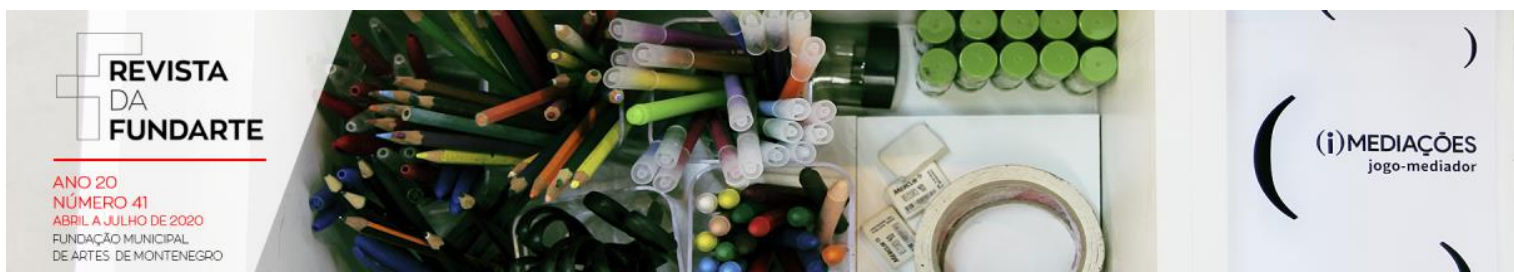

Grotowski cria uma linhagem própria, ligada ao cuidado de si e à arte como veículo.

A tradição não se configura aqui como mecanismo cristalizador de produzir teatro, mas como ferramenta que impulsiona a transformação do fazer teatral, a partir do encontro com a tradição extraída de várias culturas atravessadas pelo encontro de outras. E nessa caminhada, o actante depara-se com a existência do outro, que transeunte nos seus passos, esbarra-se e se metamorfoseia na existência do outro. Foucault (2006) afirma que o cuidado de si é uma atitude para consigo, para com os outros e para com o mundo. Abarca uma prática ligada à atenção sobre si mesmo, um modo de estar atento ao que se passa em si e no mundo. Desse modo, o cuidado de si concretiza-se em ações sobre si. E não se trata de um cuidado egocêntrico ou de um trabalho para si, e sim de como através do outro encontramos uma memória individual e coletiva esquecidas, metamorfoseadas, uma história passada que interfere no presente do universo humano. Em uma sociedade globalizada, Madeira (2010, p. 49) comenta que sua dinâmica detém, na visão de Jameson, "um processo dual da particularização do universal e da universalização do particular" [Jameson, 1999:xi]; e na de Pieterse, que existe "a valorização global das identidades particulares" [Pieterse, 1994], ambas referências indicadas por Madeira. As referidas memórias poderiam ser resgatadas por um ritual proposto no trabalho do Open Program of Workcenter...., cuja definição de ritual é tratada por Schechner (2013, p. 49) como "memórias em ação, codificadas em ações"12.

\section{Rumo ao Encontro em um Terreno Sagrado}

Nos quatro dias de exercícios com seis horas diárias, após realizar os exercícios de ações físicas e vocais e dos respaldos de Mario Biagini, despertou-se grande curiosidade sobre a hibridez cultural experimentada pelos cantos de tradição

\footnotetext{
12 Tradução minha.
}

PIVA, Bruno Leal. Em busca de um teatro sagrado: encontros e travessias no Open Program of Workcenter of J. Grotowski and T. Richards. Revista da FUNDARTE. Montenegro, p.01-21, ano 20, no 41, Abril/Junho de 2020.

Disponível em: http://.seer.fundarte.rs.gov.br/index.php/RevistadaFundarte/index> 30 de junho de 2020. 


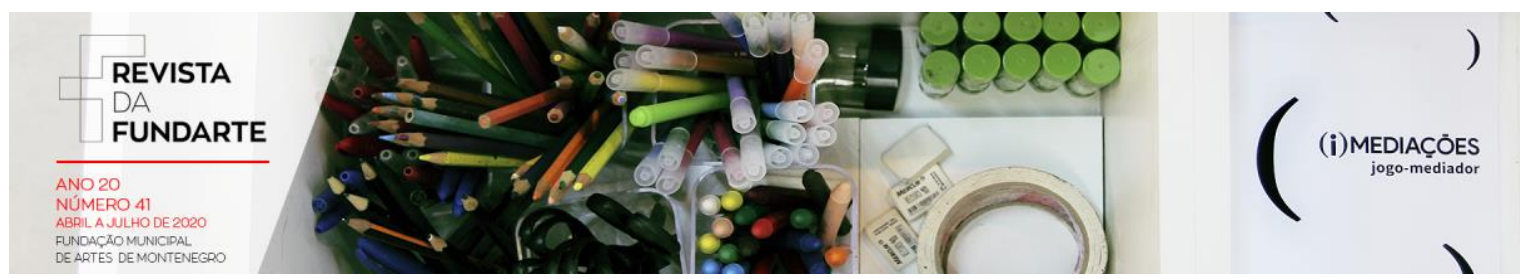

que utilizam o corpo do actante como canal que reflui impulsos extracotidianos e direcionam ao encontro de si com o outro, constatados em momentos vistos durante a oficina e dessa parceria travada. A relação sensível entre o ser humano e o estar em cena envolve o actante em uma ordem de ações, intenções e reações de fluxos que compõem as partituras da dramaturgia do actante em cena, que requer um exercício de reconhecimento profundo sobre sua intimidade.

É necessário dar-se conta de que o nosso corpo é a nossa vida. No nosso corpo, inteiro, são inscritas todas as experiências. São inscritas sobre a pele e sob a pele, da infância até a idade presente [...] Se permitirem que o seu corpo procure o que é íntimo, o que fez, faz, deseja fazer na intimidade [...] ele procura: tocar alguém, seguro a respiração, algo se detém dentro de mim, sim, sim, nisso há sempre o encontro, sempre o Outro [...] O ato do corpo-vida implica na presença de um outro ser humano [...] Esses outros estão inscritos no corpo-vida [...] E se vocês evocam com o corpo-vida o instante no qual vocês tiverem tocado alguém, aquele alguém se mostrará naquilo que vocês fazem. (GROTOWSKI, 2010a, p. 205-206)

Pode-se qualificar aqui o trabalho orgânico, sincero ou sensível numa relação com 0 encontro presente, resultantes de experimentos cênicos e suas improvisações, e da dialética em função do quadro artístico-cultural e social do qual os actantes-aprendizes pertencem, no confronto que vivenciamos entre a percepção imediata e a voz interior que se revela nos e pelos (en)cantos de experienciações invisíveis e ancestrais do instante teatral, com a pulsação de torná-las visíveis. Sobre a necessidade dos actantes utilizarem o teatro (ou corpo) como espaço para tornar as forças invisíveis visíveis, recorre-se à busca do teatro sagrado proposto por Peter Brook:

É evidente que ainda queremos captar nas artes os fluxos invisíveis que governam as nossas vidas. [...] Mesmo que o teatro tivesse tido, em suas origens, rituais que possibilitassem a encarnação do invisível, é preciso não esquecer que, salvo certos teatros orientais, esses rituais se perderam ou permanecem em lenta degeneração. Precisamos montar rituais verdadeiros. Mas rituais que façam das nossas idas ao teatro uma experiência que alimente as nossas vidas. Precisamos de formas verdadeiras, mas estas não estão à nossa disposição. (Brook, 1970, p. 24)

Ainda, o encenador inglês explica que para comunicar significados invisíveis, o actante deveria concentrar-se, ter vontade e coragem, usar suas forças

PIVA, Bruno Leal. Em busca de um teatro sagrado: encontros e travessias no Open Program of Workcenter of J. Grotowski and T. Richards. Revista da FUNDARTE. Montenegro, p.01-21, ano 20, no 41, Abril/Junho de 2020.

Disponível em: http://.seer.fundarte.rs.gov.br/index.php/RevistadaFundarte/index> 30 de junho de 2020. 


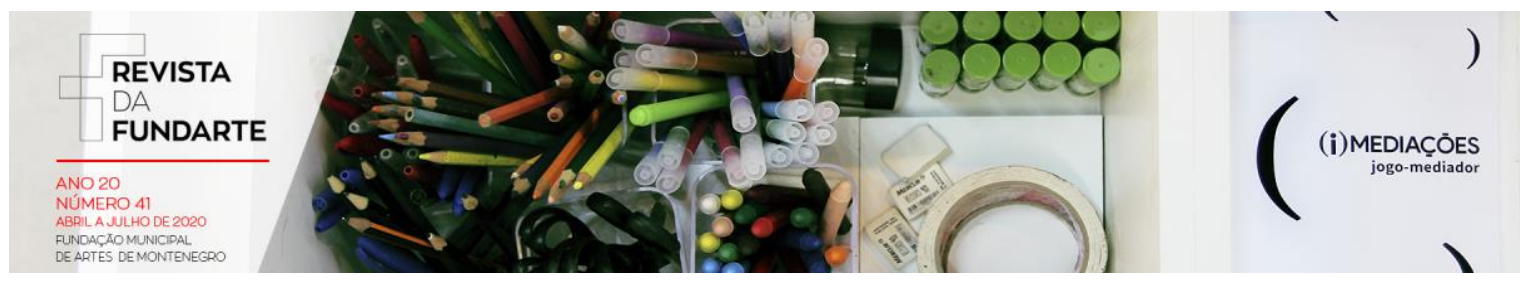

emocionais, para que conseguisse criar uma forma que refletisse seus impulsos, mostrando uma ideia invisível (BROOK, 1970). Contudo, não basta que seja utilizada apenas uma espécie de vocação passional pessoal para atingir um estado de excelência do fazer artístico, mas também é necessário que essa criação seja, conforme Tatiana Motta Lima (2013, p. 234)

ao mesmo tempo, transformação de si. Quando 'se esquece de si', o cantante é outro e é justamente esse outro que o canto recorda e faz recordar. Perde-se aqui qualquer posição previamente definida de sujeito e objeto: homem e canto estão em acoplamento, em rede.

A autora ainda concorda com a afirmação de Biagini e coloca em seu texto (2013, p. 234) que o cantar pelo homem é repleto de vida e desejos da pessoa que canta, e com isso existe algo de não pessoal que emerge, cuja pessoa passa a ser canal e cujo indivíduo não desaparece, mas está servindo como instrumento de alguma coisa.

Dentro da contemporaneidade urbana, é fundamental que estudos acerca do teatro também sejam realizados no âmbito das práticas antropológicas, com interferência de uma hibridez cultural na formação de um espaço sagrado para o actante de cena, a fim de alcançar sua organicidade, o encontro verdadeiro de si, com o outro, em simbiose. A intervenção do homem em seu contexto sociocultural é possível apenas se ele compreender e estiver consciente dos acontecimentos externos e internos que o cercam. Destaca-se, neste sentido, a discussão sobre a importância do híbrido no contexto social, segundo Madeira (2010, p. 47):

De facto, quando se fala de híbrido, mestiço, monstro ou heterogêneo, parece que os termos, enquanto sinônimos, já não assentam na existência de um polo inverso, onde se incluem categorias como puro, normal, ou homogêneo, porque qualquer coisa detém, num qualquer grau, impurezas, anormalidades, heterogeneidades. Isto leva-nos a recolocar em perspectiva o poder transgressivo e subversivo do híbrido, em relação às oposições categoriais e à sua capacidade de fomentar a reflexividade e mudança social.

No Open Program of Workcenter..., a relação do indivíduo com seu coletivo, inserido numa relação intercultural, de algum modo se entrelaça na busca de um

PIVA, Bruno Leal. Em busca de um teatro sagrado: encontros e travessias no Open Program of Workcenter of J. Grotowski and T. Richards. Revista da FUNDARTE. Montenegro, p.01-21, ano 20, no 41, Abril/Junho de 2020.

Disponível em: http://.seer.fundarte.rs.gov.br/index.php/RevistadaFundarte/index> 30 de junho de 2020. 


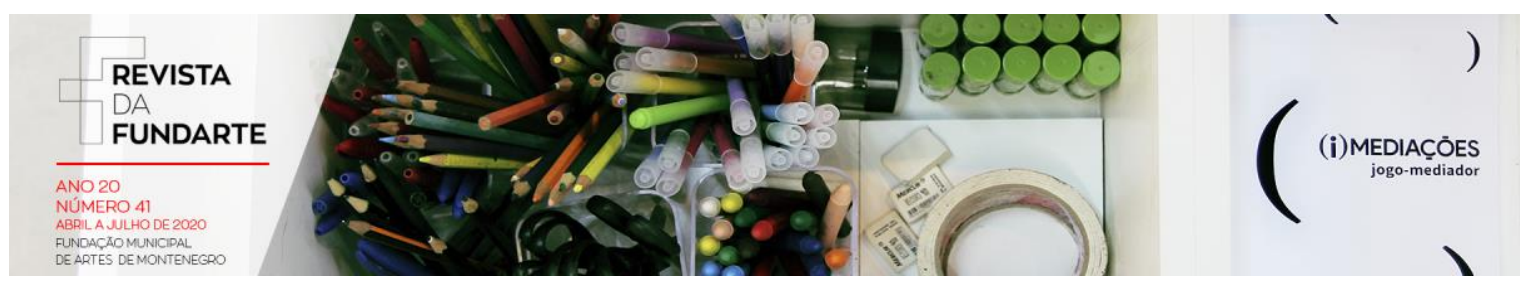

objetivo comum: de um encontro de si, ao se identificar no outro. E como cada ser é singular de uma pluralidade, dificilmente essa busca será harmoniosa, pois na vida do cotidiano e da arte os atritos e contradições fazem-se necessários para que haja um aquecimento na libertação da zona de conforto, seguido da reflexão, e partindo para o fazer da transformação.

Extremamente necessário, ainda que por impulsos de sua natureza, que o actante esteja neutralizado, limpo e aberto para o inesperado, pois em cena as ações podem conduzi-lo a um determinado tipo de julgamento que não cabe a ele, mas à esfera estabelecida no jogo com todos os envolvidos no momento dessas ações, num desvelar-se de si, num desnudamento de um solo sagrado. Na oficina essas condições eram fundamentais. Devia-se despir-se de qualquer tipo de julgamento próprio ou alheio e permitir conduzir-se ou atravessar-se pelos embalos dos cantos tradicionais afro-caribenhos, que aconteciam como uma celebração, um encontro com alguém que não se vira há muito, uma aproximação com o eu interior, atingido por meio do encontro com o outro. Como dizia Artaud (apud Peter Brook, 1970), apenas pelo teatro seria possível atingir uma libertação das maneiras limitadas cotidianas a que se submete a humanidade, e isso fazia do teatro um local sagrado. No encontro desse teatro, dessa arte como veículo do Open Program, tentava-se realizar uma espécie de autopenetração, conceito criado por Grotowski, mas bem explicitado por Peter Brook (1970, p. 33):

o teatro é um veículo, um meio de fazer auto-estudo [sic], auto-exploração [sic]; uma possibilidade de salvação [...] Na terminologia de Grotowski, o ator permite que o papel o "penetre". No princípio ele tem muitos obstáculos em relação ao papel, mas com o trabalho constante ele adquire comando técnico dos seus sentidos físicos e psíquicos que então lhe permitem deixar cair as barreiras. A "Autopenetração" através do papel é relacionada à coragem de se expor: o ator não hesita em se mostrar exatamente como é, pois reconhece que o segredo do papel exige que ele se abra, mostrando seus próprios segredos. Assim 0 ato de representação é um ato de sacrifício, de sacrificar o que a maioria dos homens prefere esconder - este sacrifício é uma dádiva para o espectador. Os atores de Grotowski oferecem sua representação como cerimônia para aqueles que desejam assistir; o ator invoca e mostra despido aquilo que está em cada homem e aquilo que a vida cotidiana encobre. Este teatro é sagrado porque sua

PIVA, Bruno Leal. Em busca de um teatro sagrado: encontros e travessias no Open Program of Workcenter of J. Grotowski and T. Richards. Revista da FUNDARTE. Montenegro, p.01-21, ano 20, oㅡ 41, Abril/Junho de 2020.

Disponível em: http://.seer.fundarte.rs.gov.br/index.php/RevistadaFundarte/index> 30 de junho de 2020. 


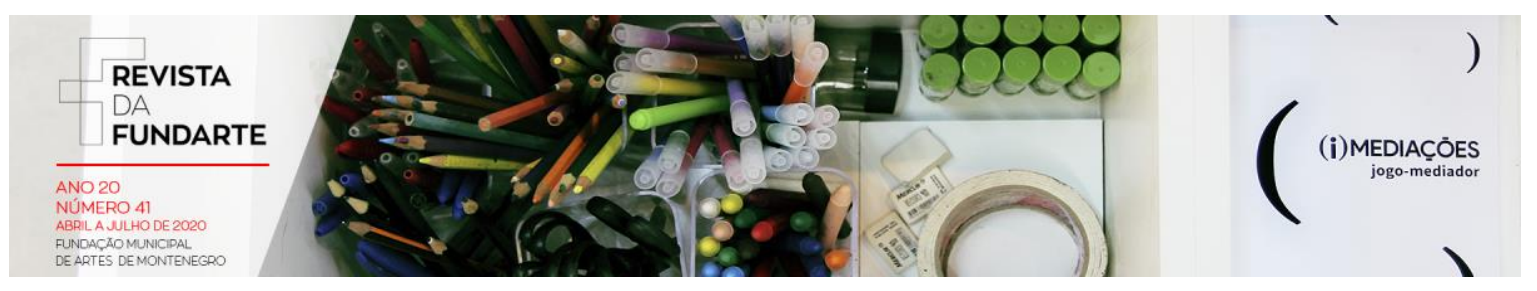

intenção é sagrada; tem um lugar claramente definido na comunidade e responde a uma necessidade que as igrejas não podem mais preencher.

Os tipos ou arquétipos apropriados pelos actantes se inscrevem, no Open Programa of Workcenter..., nas entrelinhas em que os experimentos cênicos e a participação ativa dos artistas podem construir novas formas de lidar com o corpo, a voz, os gestos e outras características que não apenas imitam e representam o ser humano, como dar vida aos sentimentos, aos elementos da natureza, aos animais, a acontecimentos, enfim, a outras formas que compõem nossa existência e que o actante, com seu corpo-voz, pode oferecer no hoje da vida, na renovação da conexão e do resgate de sensibilidade. Trata-se de um desafio trabalhado por exercícios, conforme explica Ludwik Flaszen ${ }^{13}$ (2010, p. 29), em que

[...] o exercício constitui para o ator o desafio ao qual deve encontrar resposta o seu organismo, enfrentando o risco de superar a dificuldade nele contida [...] Desafio para o ator pode ser (...) em uma esfera mais ampla: a vida. O confronto com o desconhecido. Ultrapassar o impossível.

Por meio de oficinas do grupo que circula com o Open Program of Workcenter..., constituído por actantes com formações artísticas e socioculturais distintas, são verificados os experimentos, as tentativas e os materiais que os actantes propõem para a busca de sua organicidade e o desenvolvimento de suas narrativas. A experiência tem como ponto de partida a compreensão individual de signos culturalmente coletivos, cujos códigos geram impulsos e transformam-se em ações físicas, a partir da prosódia de cantigas afro-caribenhas, repleta de ritmo e musicalidade, com o intuito de reencontrar o tempo social humano, de si e do outro, em oposição ao ritmo industrial e à comunicação imediata, como observa-se no pensamento de Eric Vautrin (2013).

\footnotetext{
${ }^{13}$ Ludwik Flaszen foi um dos maiores colaboradores e parceiros de Grotowski, que fundou junto a este o Teatr Laboratorium. Ele dispõe uma de coletânea de textos "esquecidos e memoráveis", sobretudo de Grotowski, que compõe o capítulo "De Mistério a Mistério: Algumas Considerações em Abertura", do livro Teatro Laboratório de Jerzy Grotowski: 1959-1969.
}

PIVA, Bruno Leal. Em busca de um teatro sagrado: encontros e travessias no Open Program of Workcenter of J. Grotowski and T. Richards. Revista da FUNDARTE. Montenegro, p.01-21, ano 20, no 41, Abril/Junho de 2020.

Disponível em: http://.seer.fundarte.rs.gov.br/index.php/RevistadaFundarte/index> 30 de junho de 2020. 


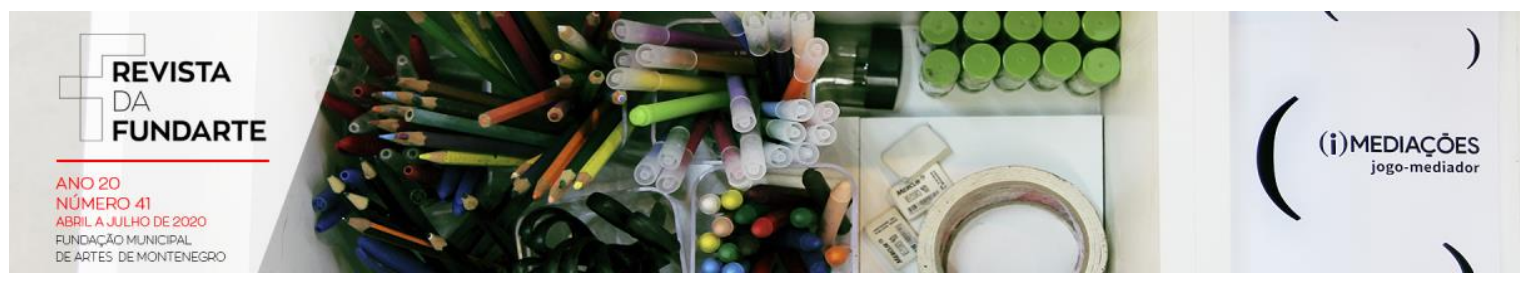

Durante o processo, os actantes levantam questionamentos ao orientador Mario Biagini sobre suas atuações e construção da narrativa cênica. Pesquisam, escrevem, discutem, usam suas vozes e seus corpos e recebem um respaldo do mestre. Muitas vezes esses materiais levantados são desconstruídos e novamente os actantes deverão iniciar seu processo. O maior benefício que se pode esperar de toda essa especulação é o próprio ser e estar do indivíduo na arte, a sublimação do ato de interferir e interagir com seu meio, de alcançar outros níveis de observações e ações, e principalmente o de se perceber como indivíduo neste mundo, a partir de uma proposta pedagógica que tem como princípio a experienciação viva dos encontros diários, em uma contradição própria do ato total de criação. Segundo Richards e Biagini, citado por Eric Vautrin (2013, p. 200)

O esplendor da vida está constantemente à espera de cada um de nós em toda a sua plenitude, mas velado à visão, enterrado nas profundezas, invisível, distante. No entanto, ele está aqui, nem hostil, nem malintencionado [sic], nem surdo. Se o convidarmos com palavra certa, pelo seu verdadeiro nome, ele virá. Essa é a essência do teatro, que não cria, mas convida.

No espaço cênico, do encontro sagrado, os actantes se descobrem, interagem, constroem, conflitam, cantam e ecoam suas vozes. Precisam se expressar com um olhar diferente para cada parceiro, e ao mesmo tempo todos devem se conectar. Os encontros são divididos em dois momentos. No primeiro momento, devem estar preparados para iniciar o treinamento, em estado de atenção. Não se faz necessário reconhecer o espaço nem se concentrar deitado para um momento de esvaziamento mental do espaço externo. O ponto exato é tentar relacionar-se com as canções caribenhas que aos poucos vão se apropriando dos participantes. Grotowski (apud Ludwik Flaszen 2010, p. 26), comenta em 1992, que "o canto se torna o próprio sentido através das qualidades vibratórias [...] Quando falo desse 'sentido' falo ao mesmo tempo também dos impulsos do corpo; isso significa que a sonoridade e os impulsos são o sentido, diretamente." Nesse

PIVA, Bruno Leal. Em busca de um teatro sagrado: encontros e travessias no Open Program of Workcenter of J. Grotowski and T. Richards. Revista da FUNDARTE. Montenegro, p.01-21, ano 20, no 41, Abril/Junho de 2020.

Disponível em: http://.seer.fundarte.rs.gov.br/index.php/RevistadaFundarte/index> 30 de junho de 2020. 


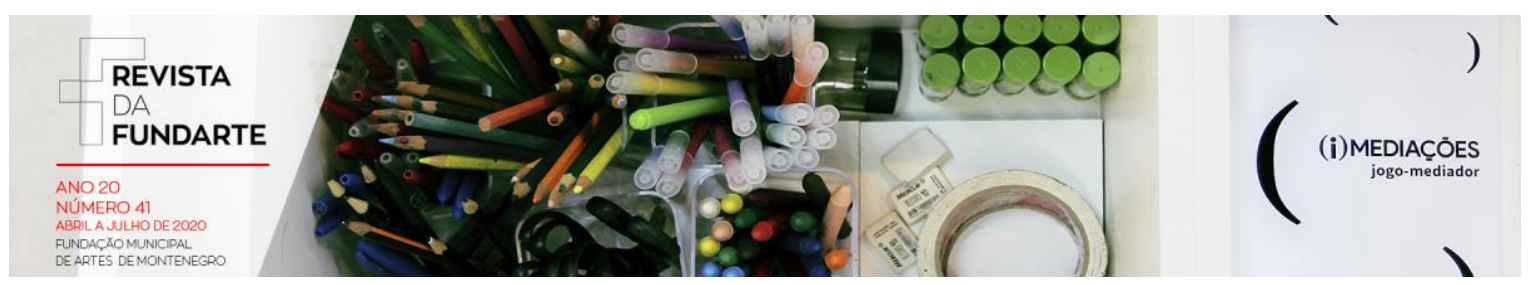

primeiro tempo do workshop, parecia haver uma mistura entre ritual, jogo e performance, como observa Schechner (2013).

No segundo tempo, os actantes apresentam suas microcenas e recebem 0 retorno de Biagini - sempre num ritmo enérgico que retira o conforto do actante desavisado. No dia seguinte, as atividades prosseguem nessa divisão entre evocar um encontro sincero e expressá-lo cenicamente, entre vaidades e frustrações pessoais, e o que realmente pode mover o actante em contradições em busca de um trabalho verticalizado de si. Essas contradições referem-se a uma alternância da qualidade de percepção entre o "eu”, o "eu-outro", o "eu no mundo" e o "eu com o mundo"14, que resultam num trabalho de verticalidade das energias potencializadas advindas de camadas ou planos subjetivamente impalpáveis, mas possivelmente concretizadas na árdua busca desse encontro extra e primordial, tão pouco explorado em nosso cotidiano. Sobre essa verticalização, Biagini (apud Lima, 2013, p. 236) aponta que

[...] na verticalidade, é aquela vaga sensação que identifico como 'eu' que muda de qualidade, como se o meu ser, a minha percepção de mim no mundo e do mundo em mim mudassem de qualidade, de densidade. [...] Há momentos em que ando pela rua e é como se vivesse e percebesse o mundo a partir de debaixo do meu umbigo: me movimento, sento, vejo, penso como se fosse um trator; a percepção, as impressões que tenho das pessoas são densas, espessas, pesadas, há algo de inerte em mim [...] Então, um segundo depois, acontece algo e imediatamente as cores são diferentes, vívidas, improvisadamente os meus pensamentos estão em uma outra relação comigo, não me pertencem; é como se, em mim, eu estivesse em um outro lugar, ou em um outro nível ou plano [...]. Não vejo mais só eles, os outros, vejo que cada um é um mistério; não existe apenas eu, mas cada coisa é 'eu', cada coisa diz 'eu'.

Assim, ocorre, por meio do processo de aprendizagem do Open Program, uma tentativa de descoberta e encontro de si, essencial para a formação de um artista teatral. Mario Biagini, ancorado pelas obras prosódicas e de escansões

\footnotetext{
${ }^{14}$ Sobre essa relação "eu-outro", Martin Heidegger (1991, p. 21-22) afirma que o homem, "o ser aí" (eu-outro) é existencialmente definido porque em si existe algo de si próprio, com o qual o "ser-aí" é guiado de algum modo por si mesmo, sendo em si também o outro no mundo (tradução e interpretação nossa).
}

PIVA, Bruno Leal. Em busca de um teatro sagrado: encontros e travessias no Open Program of Workcenter of J. Grotowski and T. Richards. Revista da FUNDARTE. Montenegro, p.01-21, ano 20, no 41, Abril/Junho de 2020.

Disponível em: http://.seer.fundarte.rs.gov.br/index.php/RevistadaFundarte/index> 30 de junho de 2020. 


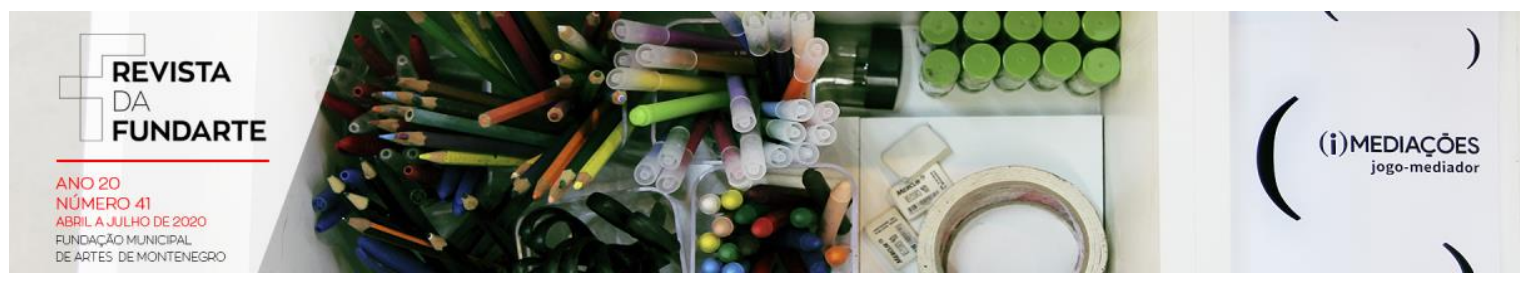

inspiradas nos cantos negros do poeta da geração beat, Allen Ginsberg, encontra este, segundo Vautrin (2013, p. 282) "no caminho dos cantos populares americanos [...] iniciado graças a um dos actantes do Open Program, Lloyd Bricken, músico americano, e continuado graças aos arquivos sonoros do antropólogo do folclore Alan Lomax", propõe as ações físicas realizadas por meio do canto:

As noções de justeza ou de tecnicidade desses cantos importam menos do que sua capacidade de envolver os corpos e os seres em suas obras. Assim, não é surpreendente ouvir, nas gravações de Lomax, vozes de avós, depois da missa, vozes desafinadas que com certeza não são as mais delicadas do grupo, mas que são certamente as mais envolventes ou inebriantes, e que vão, de fato, lançar os cânones e envolver todos e cada um no canto e na dança. Um canto leva a uma ação: eis aí como se articula e se organiza o trabalho dos atores do Open Program. O sentido de um canto não é distinto do que ele provoca e movimenta dentro do indivíduo (VAUTRIN, 2013, p. 282-283).

Com e no outro, então, emerge-se a própria subjetividade escondida nos cantos empoeirados do universo humano, esquecido pelo ritmo acelerado das vidas atribuladas e da chuva de informações que invadem e cerceiam a possibilidade de esgueirar-se sobre o abismo em direção de um encontro de si mesmo e com o outro, numa relação de reflexão e metamorfose que pode encontrar-se pela hibridez cultural e do esforço pelo fazer artístico. Busca-se, assim, no Open Programo of Workecenter..., essa sensibilidade perdida entre tantos caminhos individualistas e destroçados pelos afazeres sociais triviais, por meio de uma recuperação da humanidade que não deve escapar-nos. E, conforme Lima (2013, p. 237),

[...] é um outro de si que aparece quando o trabalho sobre si relacionado aos cantos de tradição - ancorados nos impulsos do corpo, na organicidade, e na direção da verticalidade - funcionam. [...] um euninguém, menos aferrado/identificado às construções do ego [...].

E, finalizando com as palavras da mesma autora (Ibidem, p. 231), esse trabalho de Grotowski consiste em "uma investigação transcultural na busca de técnicas eficazes - simples, dramáticas e orgânicas - de trabalho sobre si”.

PIVA, Bruno Leal. Em busca de um teatro sagrado: encontros e travessias no Open Program of Workcenter of J. Grotowski and T. Richards. Revista da FUNDARTE. Montenegro, p.01-21, ano 20, no 41, Abril/Junho de 2020.

Disponível em: http://.seer.fundarte.rs.gov.br/index.php/RevistadaFundarte/index> 30 de junho de 2020. 


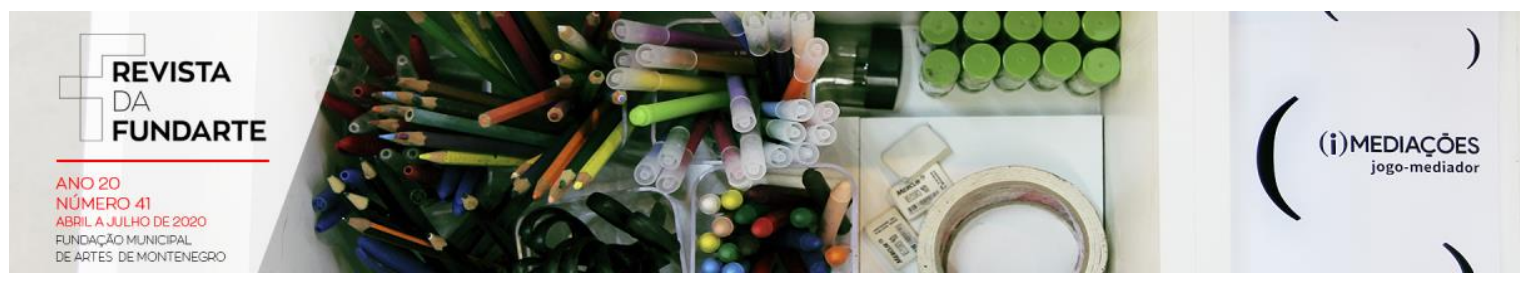

\section{Conclusão ou Ponto de Encontro e Chegada}

Para melhor vislumbrar o percurso do pensamento de Grotowski, parte-se do plano horizontal entre actante e espectador/testemunha no Teatro dos Espetáculos, em que o eixo se baseia na preparação técnica. Este segue com os impulsos ocasionados pelo cruzamento com o segundo, resultando na fase posterior que é o parateatro, com participação ativa dos participantes e, depois de modo mais restrito, ao trabalho solitário do actante sobre si mesmo no Teatro das Fontes.Essas influências desembocam no surgimento da arte como veículo, num plano verticalizado de entendimento sobre si e, consequentemente, pelo e sobre o outro, no encontro que ativa um novo eixo e possibilita a expansão energética da complexidade híbrida existencial, culminando num ato total.

O gráfico ilustrativo abaixo sugere o que poderia ser esse processo contínuo de metamorfose, desses pontos de relação de aspectos heterogêneos que se complementam e se totalizam:

Figura 1 - A intersecção ou ponto de encontro na trajetória do teatro grotowskiano, ou do encontro de si no e com o outro, resulta na irradiação de impulsos e fluxos, que culminam no ato total. As vias transversais também podem ser vistas como o cruzamento de influências de culturais híbridas, que do mesmo modo, conduzem a um encontro sincero de experienciações ancestrais e memoriais.

Fonte: Autoria própria

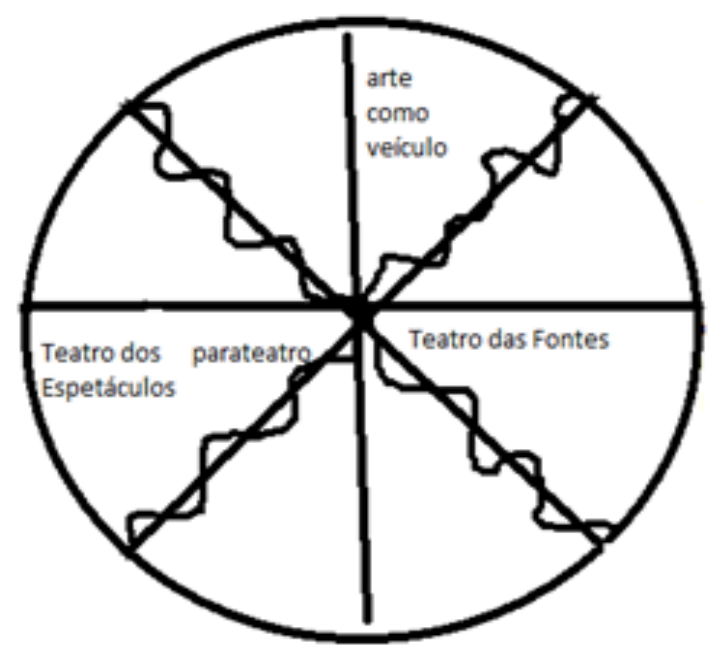

PIVA, Bruno Leal. Em busca de um teatro sagrado: encontros e travessias no Open Program of Workcenter of J. Grotowski and T. Richards. Revista da FUNDARTE. Montenegro, p.01-21, ano 20, no 41, Abril/Junho de 2020.

Disponível em: http://.seer.fundarte.rs.gov.br/index.php/RevistadaFundarte/index> 30 de junho de 2020. 


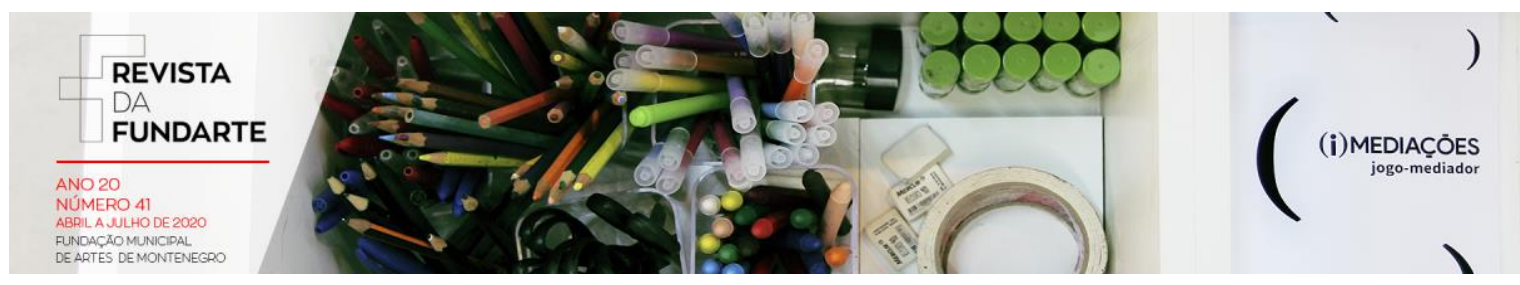

\section{Referências:}

ARTAUD, Antonin. O teatro e seu duplo. São Paulo: Martins Fontes, 2006.

ATTISANI, Antonio. O Século de Jerzy Grotowsk. Revista Brasileira de Estudos sobre a Presença., Porto Alegre, v. 3, n. 1, p. 20-38, jan./abr. 2013. Disponível em: http://www.seer.ufrgs.br/presenca. Acessado em 16 de novembro de 2017.

BARBA, Eugênio. A Terra de Cinzas e Diamantes. São Paulo: Perspectiva, 2006.

BONFITTO, Matteo. O Ator Compositor. As Ações Físicas como Eixo: De Stanislávski a Barba. São Paulo, Perspectiva, 2013.

BROOK. Peter (1970). O teatro e seu espaço. Petrópolis: Vozes. Edição digital em $<$ www.desvendandoteatro.com $>$. Acessado em 14 de novembro.

CALVERT, Dorys F. Desconstruindo Grotowski. Revista Brasileira de Estudos sobre a Presença., Porto Alegre, v. 3, n. 1, p. 341-347, jan./abr. 2013. Disponível em: http://www.seer.ufrgs.br/presenca. Acessado em 19 de novembro de 2017.

DOMINICK, Barbara. The Open Program of The Workcenter and Dr. Drum at Andrew Freemam House. New York, 2016.

ELIAS, Larissa. Brook avec Grotowski: testemunho da vida e da arte de um certo polonês. R. bras. est. pres., Porto Alegre, v. 3, n. 1, p. 353-359, jan./abr. 2013. Disponível em: http://www.seer.ufrgs.br/presenca. Acessado em 20 de novembro de 2017.

FLASZEN, Ludwik; POLLASTRELLI, Carla. Teatro Laboratório de Jerzy Grotowski, 1959-1969. São Paulo: Fondazione Pontedera teatro/Sesc - SP/Perspectiva, 2010.

FOUCAULT, Michel. A Hermenêutica do Sujeito. São Paulo: Martins Fontes, 2006.

GROTOWSKI, Jerzy. Em busca de um teatro pobre. Rio de Janeiro: Civilização Brasileira, 1971.

Em Busca de um Teatro Pobre. In: FLASZEN, Ludwik; POLLASTRELLI, Carla. (Org.) O Teatro Laboratório de Jerzy Grotowski 1959-1969. São Paulo: Perspectiva, 2010. p. 105-112.

PIVA, Bruno Leal. Em busca de um teatro sagrado: encontros e travessias no Open Program of Workcenter of J. Grotowski and T. Richards. Revista da FUNDARTE. Montenegro, p.01-21, ano 20, no 41, Abril/Junho de 2020.

Disponível em: http://.seer.fundarte.rs.gov.br/index.php/RevistadaFundarte/index> 30 de junho de 2020. 


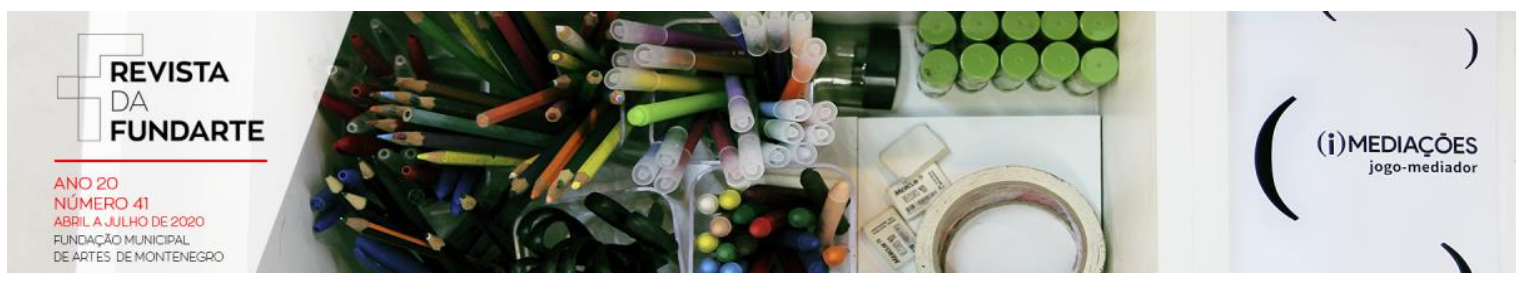

O Diretor como espectador de Profissão. In: FLASZEN, Ludwik; POLLASTRELLI, Carla. (Org.) O Teatro Laboratório de Jerzy Grotowski 1959-1969. São Paulo: Perspectiva, 2010a. p. 212-225.

HEIDEGGER, Martin. Necesidad, estructura y preeminencia de La pregunta que interroga por el ser. El ser y el tiempo. Madrid: Fondo de Cultura Económica, 1991.

Lab Buster Keaton - Scienze della Comunicazione. (2015). \#AKROPOLIS2015 /// WORKCENTER III THE HIDDDEN SAYINGS. Disponível em https://www.youtube.com/watch?v=ug7DGiDMT3U. Acesso em 04/12/2017.

LEHMANN, Hans-Thies. O teatro pós-dramático. São Paulo: Cosac Naify, 2007.

LIMA, Tatiana M. "Cantem, pode acontecer alguma coisa": em torno dos cantos e do cantar nas investigações do Workcenter of Jerzy Grotowski and Thomas Richards. Revista Brasileira de Estudos da Presença, Porto Alegre, v. 3, n. 1, p. 220-240, jan./abr. 2013. Disponível em http//:www.seer.ufrgs.br/presenca. Acessado em 17 de novembro de 2017.

MADEIRA, Cláudia. Híbrido - do Mito ao Paradigma Invasor? Lisboa: Mundos Sociais, 2010.

MENDONÇA, Patricia F. Trabalhar com Grotowski sobre as Ações Físicas Revista Brasileira de Estudos sobre a Presença, Porto Alegre, v. 3, n. 1, p. 360-370, jan./abr. 2013. Disponível em: http://www.seer.ufrgs.br/presenca. Acessao em 18 de novembro de 2017.

Open Program of Workcenter of Jerzy Grotowski and Thomas Richards. Disponível em: <http:// http://www.theworkcenter.org/. Acessado em 20 de setembro de 2015.

Open Program Workcenter of Jerzy Grotowski and Thomas Richards. (2015). Electric Party Songs - Every Time. Macao. Disponível em https://www.youtube.com/watch?v=msaXMBBCaQ Acesso em 04/12/2017.

PLÁ, Daniel Reis. Tornar-se Filho de Alguém: reflexões sobre organon, técnica e tradição em Grotowski. Revista Brasileira de Estudos sobre a Presença, Porto Alegre, v. 3, n. 1, p. 144-163, jan./abr. 2013. Disponível em: http://www.seer.ufrgs.br/presenca. Acessado em 17 de novembro de 2017.

RICHARDS, Thomas. Trabalhar com Grotowski sobre as ações físicas. São Paulo, Editora Perspectiva, 2012.

PIVA, Bruno Leal. Em busca de um teatro sagrado: encontros e travessias no Open Program of Workcenter of J. Grotowski and T. Richards. Revista da FUNDARTE. Montenegro, p.01-21, ano 20, no 41, Abril/Junho de 2020.

Disponível em: http://.seer.fundarte.rs.gov.br/index.php/RevistadaFundarte/index> 30 de junho de 2020. 


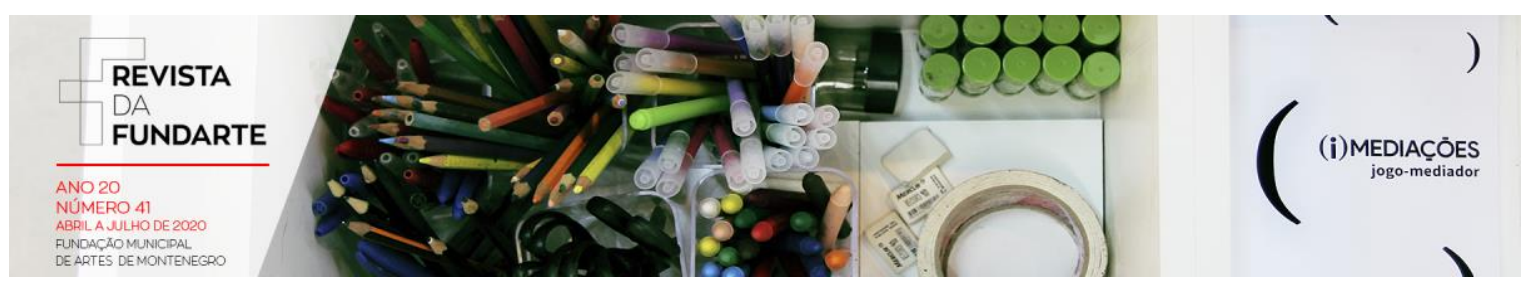

SCHECHNER, Richard. Performance Studies: an Introduction. 3르 edição. New York: Routledge, 2013.

SCHECHNER, Richard. Performance Theory. New York: Routledge Classics, 2003.

VAUTRIN, Éric. Uma Arte do Encontro. Revista Brasileira de Estudos sobre a Presença, Porto Alegre, v. 3, n. 1, p. 275-286, jan./abr. 2013. Disponível em: <http://www.seer.ufrgs.br/presenca>. Acessado em 18 de novembro de 2017.

YARROW, Ralph. Grotowski, Holiness and Pre-Expressive. Contemporary Theater Review, Amsterdã, v. 7, part 1, pp. 25-34, 1997.

PIVA, Bruno Leal. Em busca de um teatro sagrado: encontros e travessias no Open Program of Workcenter of J. Grotowski and T. Richards. Revista da FUNDARTE. Montenegro, p.01-21, ano 20, no 41, Abril/Junho de 2020.

Disponível em: http://.seer.fundarte.rs.gov.br/index.php/RevistadaFundarte/index> 30 de junho de 2020. 